\title{
Relationship between distributed leadership, teacher collaboration and organizational innovativeness
}

\author{
Ömür Çoban ${ }^{1}$, Ramazan Atasoy ${ }^{2}$ \\ ${ }^{1}$ Faculty of Education, Karamanoglu Mehmetbey University, Turkey \\ ${ }^{2}$ Turkish Ministry of National Education, Turkey
}

\section{Article Info \\ Article history: \\ Received Apr 20, 2020 \\ Revised Sep 28, 2020 \\ Accepted Oct 16, 2020}

\section{Keywords:}

Distributed leadership

Organizational innovativeness

School principal

TALIS

Teacher collaboration

\begin{abstract}
The aim of this study was to examine the relationships between distributed leadership, organizational innovativeness and teacher collaboration. We used Turkish teacher data and conducted the analysis from teachers' perspectives working in secondary schools in Turkish Ministry of National Education at the International Standard Classification of Education 2 (ISCED) level. In this quantitative study, we analysed the three hypotheses via structural equation model. The hypotheses assumed that there was a relationship between distribute leadership and organizational innovativeness, also there was a relationship between distrubitive leadership and teacher collaboration. Additionally, there was a relationship between teacher collaboration and organizational innovativeness. Finally, we analysed the impact of distributed leadership on organizational innovativeness via teacher collaboration. The finding indicated that there were relations between distributed leadership and organizational innovativeness. The other result showed that teacher collaboration affected organizational innovativeness. The last finding displayed that distributed leadership impacted organizational innovativeness via teacher collaboration. In conclusion, if school principals exhibited distributed leadership behavior, they would create a supportive and collaborative climate for teachers and they also encourage teachers' agreement to develop new ideas for teaching, their openness to change, their problem-solving strategies and exchanging atmosphere where they share their practices with each other.
\end{abstract}

This is an open access article under the CC BY-SA license.

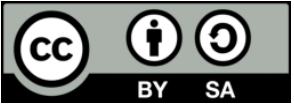

\section{Corresponding Author:}

Ramazan Atasoy,

Turkish Ministry of National Education,

Mamak Ilce Milli Egitim Müdürlügü, Mamak, Ankara, Turkey.

Email: atasoyramazan@gmail.com

\section{INTRODUCTION}

Many researches in Educational Administration (EA) have focused on school improvement practices and school leadership roles and observed the influences of them on school structure, processes and outcomes. Academicians have tried to understand that what kind of school leadership roles and practices affects school improvement. Previous studies expressed that the leadership styles such as instructional leadership [1, 2], transformational leadership [3, 4], strategic leadership [5, 6] and distributed leadership [7,8] are effective to achieve organizational goals and to meet people's need and desires. These papers confidently suggested that school leadership behaviors are at the heart of school improvement and teaching processes $[9,10]$.

Available literature indicates that school principals' leadership roles are vital for school outcomes [11, 12]. They also expressed that school principals can achieve school goals by creating a 
supportive teaching climate $[13,14]$, as well as experiencing more job satisfaction [15], feeling greater selfefficacy [14], and transforming the organization into learning organization [16]. Today's knowledge about school principals' leadership roles has little empirical evidence considering how effective leadership is defined, as well as whether and to what extent it influences the processes and outcomes of schools in the context of developing nations [17]. Therefore, we aim to focus on the impact of school leadership on teachers' behaviors and emotions, as well as its influence on transforming organizations into learning and innovative organizations in Turkey, by comprehending the relations among some critical variables for school improvement, such as teachers' collaboration [9, 14] and organizational innovation [18-20] in this study. More specifically, the current research aims to provide an understanding of the extent to which principals' distributed leadership behaviors impact teacher collaboration and organizational innovativeness.

In Turkish education system, though the aim is to empower local authorities and schools over the past three decades, The Ministry of National Education (MoNE) is the main actor for the decision-making included staffing, budgeting, planning, and monitoring teaching learning activities in all over the country. Hence, school principals have lack of authority to manage instructional practices in their schools because they have little budget, no authority to select their staff, and to manage the curriculum. Under these circumstances, they have to improve their schools, create a supportive teaching atmosphere and make their organizations innovative. In this paper, we intended to indicate how school principals behave to focus on teaching and how they influence teacher collaboration, and how they transform their organizations into innovative institutions according to Teaching and Learning International Survey (TALIS) 2018 data set. The results of this research would contribute to get deeper knowledge in the literature about distributed leadership and its effects on teacher collaboration and organizational innovativeness. It could also contribute to developing countries which have similar educational policies and structures in Turkey.

The conceptual framework is based on the studies that have indicated the relation among distributed leadership, teacher collaboration and organizational innovativeness in EA (Figure 1). The data obtained from TALIS 2018 data set. Consistent with the previous studies, we built the paper on distributed leadership behaviors [21] and theirs effect on teacher collaboration [22] and organizational innovativeness [23]. We, firstly, assumed that school principals distribute leadership behaviors impact on organizational innovativeness. Then, we proposed that their distributed leadership behaviors influence teacher collaboration. Next, we presumed that teacher collaboration affects organizational innovativeness. Finally, we also claimed that school principals' distributed leadership behaviors influence organizational innovativeness via teacher collaboration. The structural equation model (SEM) of the study have got three hypotheses.

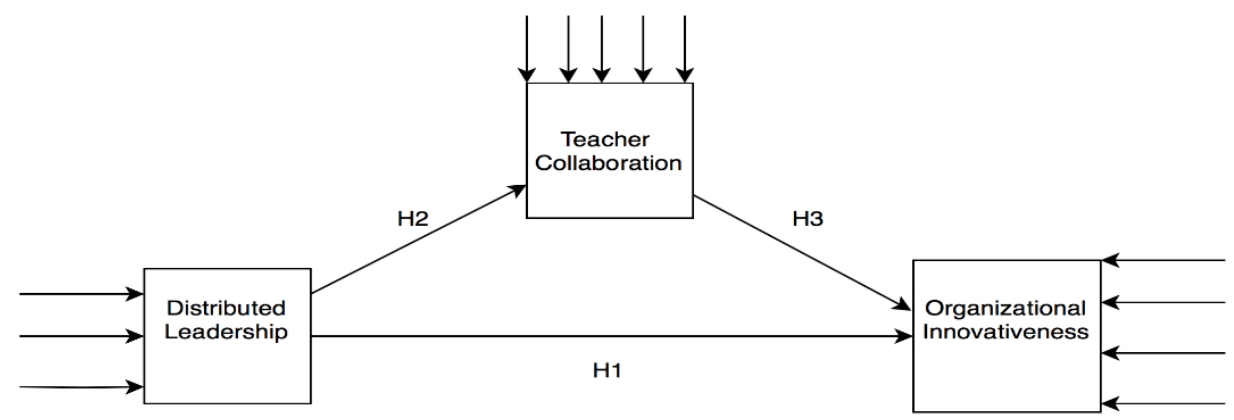

Figure 1. The SEM model of the research

In the following section, we discussed theoretical and empirical bases of each variables and we debated each hypothesis separately. Shortly, the purpose of this study is to expand and deepen the understanding of the relationships between distributed leadership (DL) and organizational innovativeness (OI) and teacher collaboration (TC), and to what extent. The research questions have guided the study: 1) There are significant and direct relationships between principal's perceived distributed leadership and organizational innovativeness (Hypothesis 1), and teacher collaboration (Hypothesis 2); 2) Teacher collaboration mediates the relationship between distributed leadership of school principals and organizational innovativeness according to the perceptions of teachers? (Hypothesis 3 ).

Researchers conducted many studies on distributed leadership [21, 24] and they examined this type of leadership on schools. Groon [25] and Spillane [26] have defined it as an interactive process among leaders, followers and situations, and they have focused on collaboration and sharing of authority. In their 
definition, the common and vital keywords are managing simultaneously and being interactive in the process. In school practices, this approach gives opportunity to school principals for collaboration, cooperation, empowerment, and sharing authority in their schools. In this concept, distributed leadership is very close to teacher leadership because school principals empower teachers and enable them to use initiative in their classroom practices and out of classroom [27, 28]. In other words, school principals create a supportive, cooperative, collaborative climate for teachers in every processes and practices. This study inspired by TALIS experts' approach and they claimed that distribution leadership provide teachers, parents and students well opportunity to actively participate in decision process at school [29]. Hence, school principals take decisions about school practices with shared mind of teachers, students and parents. In such a school culture where school principals shared their responsibilities and authorities among other school actors, they encourage collaborative climate and improve their school outputs. Shortly, if school principals behave as a distributed leader, they create a collaborative atmosphere in their schools [30]. Therefore, we assume that, when school principals act with shared mind of school actors, teachers are more likely to collaborate for school practices (Hypothesis 1).

In EA researches, the concept of collaboration is related social learning and adult learning theories. In educational area, this concept regarded as teacher collaboration and mainly emphasized creating and improving the learning environment by providing opportunities for individuals to work collectively and learn from each other [31, 32]. In other words, teacher collaboration described as teachers' experiences in exchanging information with their peers [22].

The core concepts of teacher collaboration are collaborative climate, professional learning community, professional development and fostering change in teaching [33]. School principals have key roles to create this atmosphere. As mentioned above, if school principals behave as a distributed leader, they create a collaborative atmosphere in their schools. In our study, we used the definition of TALIS experts. They argued that if school principals frequently observe classroom practices, give feedback to teachers, focus on learning development, work with teachers closely and encourage teachers to take part in collaborative professional learning, they can set up teacher collaboration in their school. Teachers who work in a collaborative and supportive environment can easily focus on classroom practices. Above all, teachers can focus on learning innovation and develop new ideas for teaching [23]. Additionally, teachers' problemsolving skills and their ability of openness to change and supporting each other for practical usage of practices increase [33]. Therefore, we propose that teacher collaboration have a positive impact on organizational innovativeness (Hypothesis 2).

The term of organizational innovativeness is based on change management approach. While planning was at the forefront of organizational change in the $1960 \mathrm{~s}$, the system approach came to the fore in the 1970-1980s. Total quality approach came to the fore in the late 1980s and 1990s [34]. In the mid-1990s, Senge [16] introduced the learning organizations approach with the fifth discipline approach and stated that the concept of learning organization is an important factor in the change of organizations. The aim of these views generally is to examine how organizations show innovative behaviors consistently over time [18]. In education, organizational innovativeness mostly focuses on creating a learning organization in order to adopt the innovative processes and approaches and respond the environmental changes quickly [18-20]. In educational sector, this term considered as adaption of schools to innovative processes and practices. To do this, school principals should behave as distributed leaders and they should create common shared vision for their schools. Besides this, as Gümüş, et al. [30] expressed that school principals create a supportive, collaborative environment for their teachers. In our paper, organizational innovativeness is taken from TALIS 2018, referring teachers' agreement to develop new ideas for teaching, their openness to change, their problem-solving strategies and exchanging atmosphere where they share their practices with each other [29]. Principals affect organizational innovativeness directly with their leadership behaviors and they also indirect impact on organizational innovativeness via teachers by creating supportive, collaborative climate in their schools.

\section{RESEARCH METHOD}

The current study which focused the relationships between the perceived distributed leadership of school principals, teacher collaboration and organizational innovativeness is performed in a relational survey model. It is a model used to determine the presence or level of co-change with two or more variables [35]. In the research, it was examined perceived distributed leadership styles of school principals according to the perceptions of teachers. The mediator role of the teacher collaboration in the relationship between the distributed leadership and organizational innovativeness is tested based on TALIS 2018 data. 


\subsection{Sampling}

The data used in this study was obtained from TALIS, which was conducted and collected in 2018 by the Organization for Economic Cooperation and Development (OECD). In the TALIS 2018 survey, canonical sampling design was used during the sampling process. Sampling design of each participating country was drawn at two stages by the cooperation with central consortium and national team accordance with the OECD terms of reference (TOR), corresponding to the survey population as defined and described on the sampling forms.

For this study, we only used Turkish teacher data and conducted the analysis from teachers' perspectives working in secondary schools in Turkish Ministry of National Education (MoNE) at the ISCED 2 level. Turkey random sampling is consisted of 200 schools and their principals from 16628 ISCED level 2 schools and about 20 teachers within each school (3952 teachers). Schools were sampled with a probability proportional to size. Before carrying out analyses, all the questionnaires were controlled if any of them were incomplete. Those of which are incomplete or imprecisely filled were opted out (25) from the analyses and, nine of the questionnaires were not taken into consideration. A sample of 3952 teachers comprises $57.8 \%$ (n $=2286)$ women and $42.2 \%(n=1666)$ men. Based on the age group of teachers, 65 of teachers are under 25 years old $(1.6 \%) ; 739$ of them are between $25-29$ years old $(18.7 \%) ; 1862$ of them are between $30-39$ years old $(47.1 \%) ; 270$ of them are between 50-59 years old (6.8\%) and 58 of teachers are 60 and above years old $(1.5 \%)$. Based on the work experience as a teacher, 711 of teachers $(24.7 \%)$ have a 5 years or less professional seniority; 889 of teachers $(22.7 \%)$ have $6-10$ years of professional seniority; 801 of teachers $(20.4 \%)$ have $11-15$ years of professional seniority; 672 of teachers $(17.1 \%)$ have $16-20$ years of professional seniority, and 594 of them $(15.1 \%)$ have 21 years or more.

\subsection{Data collecting tools}

In this study, we had used TALIS 2018 teacher questionnaire. It was collected on line, adapted the items, translated into the Turkish language, vetted for linguistic equivalence by the collaboration national study teams and TALIS questionnaire teams. The variables were selected according to pay attention the TALIS 2018 framework and relevant literature. In this context, distributed leadership is composed of 3 items; teacher collaboration of 5 items, and organizational innovativeness 4 items. Distributed leadership and organizational innovativeness scales are four-point Likert ranging from "strongly disagree" (1) to "strongly agree" (4) with the exception of the teacher collaboration scale which ranges from "never" (1) to "once a week or more" (6). In the adaptation study of the instrument, Cronbach alpha and Confirmatory Factor Analysis (CFA) re-calculated again. CFA results showed that the model (DL, TC and OI) fit the data better. Additionaly, it was found that the Cronbach's alpha values and CFA fit indices were consistent with the international TALIS technical report findings. The results of TALIS 2018 technical report and our model are given in Table 1.

Table 1. Cronbach alpha, CFA results of TALIS 2018 technical report and our model

\begin{tabular}{|c|c|c|c|c|c|c|c|}
\hline Model/fit indices & $\begin{array}{c}\chi^{2} / \mathrm{df} \\
138,169 / 49\end{array}$ & $\begin{array}{c}\text { RMSEA } \\
.022\end{array}$ & $\begin{array}{c}\text { SRMR } \\
.016\end{array}$ & $\begin{array}{l}\text { TLI } \\
.990\end{array}$ & $\begin{array}{l}\text { CFI } \\
.993\end{array}$ & $\begin{array}{c}\text { CMIN/DF } \\
2.819\end{array}$ & \\
\hline \multirow[t]{2}{*}{ Variables } & Items & FLT** & $\mathrm{MFL}^{*}$ & SE & P-Value & $\alpha^{1}$ & $\overline{\alpha^{2}}$ \\
\hline & DLA & 0.891 & 0.66 & 0.009 & 0.000 & & \\
\hline \multirow[t]{3}{*}{ Distributed Leadership } & DLB & 0.763 & 0.85 & 0.017 & 0.000 & 0.83 & 0.88 \\
\hline & DLC & 0.793 & 0.76 & 0.015 & 0.000 & & \\
\hline & OIA & 0.904 & 0.90 & 0.006 & 0.000 & & \\
\hline \multirow{5}{*}{ Organizational Innovativeness } & OIB & 0.931 & 0.93 & 0.024 & 0.000 & & \\
\hline & OIC & 0.932 & 0.94 & 0.006 & 0.000 & 0.89 & 0.89 \\
\hline & OID & 0.901 & 0.89 & 0.007 & 0.000 & & \\
\hline & TCB & 0.432 & 0.64 & 0.022 & 0.000 & & \\
\hline & TCC & 0.422 & 0.79 & 0.024 & 0.000 & & \\
\hline \multirow[t]{3}{*}{ Teacher Collaboration } & TCE & 0.610 & 0.82 & 0.020 & 0.000 & 0.87 & 0.87 \\
\hline & TCF & 0.727 & 0.86 & 0.017 & 0.000 & & \\
\hline & $\mathrm{TCH}$ & 0.695 & 0.58 & 0.018 & 0.000 & & \\
\hline
\end{tabular}

\subsection{Analysis of data}

Data were analysed using Mplus 6.2, AMOS 23, and SPSS for Windows 23 programme. The data model set was analysed from the 3927 data. Frequency and percentage values were calculated to determine the demographic characteristics of teachers (gender, age group, seniority and school location). In the analysis of the data, arithmetic means, standard deviation, frequency, Pearson correlation, regression, path analysis were used. First, all data to be selected in the research were checked concerning the assumptions of 
normality, missing values, outlier, multicollinearity and variance homogeneity. It is fixed no outliers data; VIF scores to be lower than 3. (1.109); Durbin Watson scores of all data range between 1.711 and 1.716. In addition to this, the tolerance values scores of the selected data range were found .905 , and the CI value is found 1.00 according to the linear regression model. Normality assumption was also checked and skewness and kurtosis values were found to be less than \pm 1.5 [36].

Mplus 6.2 software was used for the structural equation modelling (SEM) analysis of the data. The measurement and the structural models were tested using Maximum Likelihood Estimation (MLE) technique and covariance matrix. In the mediation effect analysis, the non-recursive causal model for determining a mediating model was used based on Baron and Kenny [37]. All assumptions concerning the mediation model are followed step by step: First, the independent variables (DL) must predict the dependent variables (OI and TC). Secondly, the mediator (TC) must predict the dependent (OI) variables when the independent variable is controlled. Thirdly, the direct effects must be non-significant for a full mediated effect. In interpreting the model, it is used Chi-Square/Degrees of Freedom) ratio $(\chi 2 / \mathrm{df} \leq 3)$ and the fit indicators such as SRMR $(\leq$ $.050)$, RMSEA $(\leq .070)$, CFI, GFI, AGFI, IFI, TLI $( \pm .85)$ are examined $[36,38,39]$.

\section{RESULTS AND DISCUSSION}

As descriptive statistics, it is presented the results of latent variables in Table 2. Means, standard deviation values and Pearson correlation of latent variables are reported in this part. Table 2 shows us that the teachers' perception of distributed leadership styles $(\overline{\mathrm{x}}=2.90 ; \pm .68)$; teacher collaboration $(\overline{\mathrm{x}}=3.02 ; \pm .75)$, and organizational innovativeness are on a $(\overline{\mathrm{x}}=3.17 ; \pm 1.12)$ medium level respectively. There are positive correlations between latent variables ranging from .28 to .40. It is found a low-level relationship between the DL and TC $(r=.28)$ and OI (.40). In addition, it is found that there is a medium level relationship between the OI and TC $(r=.34)$.

Table 2. Descriptive statistics and Pearson correlation analysis findings on research variables

\begin{tabular}{cccccc}
\hline Variables & $\overline{\mathrm{x}}=/ \mathrm{sd}$ & $\overline{\mathrm{x}} * / \mathrm{sd}$ & $\mathrm{DL}$ & $\mathrm{TC}$ & TIN \\
\hline Distributed Leadership & $2.87(.678)$ & $2.90(.683)$ & - & & \\
Teacher Collaboration & $3.01(.738)$ & $3.02(.752)$ & $.28^{* *}$ & - & \\
Organizational Innovativeness & $3.17(1.11)$ & $3.20(1.12)$ & $.40^{* *}$ & $34 * *$ & - \\
\hline *. Weighted mean. **. Correlation is significant at the 0.01 level (2-tailed). &
\end{tabular}

\subsection{Measurement model}

The structural models were tested step by step. In Table 3, it was reported the goodness of fit ( $\chi 2$, df, RMSEA, SRMR, TLI, CFI, CMIN/DF) according to the all hypothesises. Table 3 indicates that all of the structural models analysed were found have good fit values. After that process, the structural model suggested in the research was tested based on the significance of the coefficients and the results were presented with the mediation analysis results in Table 4 and Figure 2.

Table 3. Goodness of fit indices

\begin{tabular}{ccccccc}
\hline \multirow{2}{*}{ Model } & $\chi^{2} / \mathrm{df}$ & RMSEA & SRMR & TLI & CFI & CMIN/DF \\
\hline $\mathrm{DL} \rightarrow \mathrm{OI}^{*}(\mathrm{H} 1)$ & $46.729 / 12$ & 0.027 & 0.009 & 0.990 & 0.992 & 3.894 \\
$\mathrm{DL} \rightarrow \mathrm{OI}^{*}(\mathrm{H} 2)$ & $55.529 / 17$ & 0.024 & 0.020 & 0.986 & 0.992 & 3.266 \\
$\mathrm{TC} \rightarrow \mathrm{OI}^{*}(\mathrm{H} 3)$ & $92.918 / 25$ & 0.022 & 0.015 & 0.990 & 0.989 & 3.716 \\
$\mathrm{DL} \rightarrow \mathrm{TC} \rightarrow \mathrm{OI}^{*}$ & $138,169 / 49$ & .022 & .016 & .990 & .993 & 2.819 \\
\hline
\end{tabular}

Table 4. Regression results of the models

\begin{tabular}{|c|c|c|c|c|}
\hline Model & & & $* * * *$ & \\
\hline Hypothesis & $\mathrm{B}$ & SE & Est. & $\mathrm{p}^{*}$ \\
\hline $\left.\mathrm{DL} \rightarrow \mathrm{OI}^{*} \mathrm{H} 1\right)$ & .403 & .025 & 16.359 & $.001 * *$ \\
\hline $\left.\mathrm{DL} \rightarrow \mathrm{TC}^{*} \mathrm{H} 2\right)$ & .281 & .027 & 10.353 & $.001 * *$ \\
\hline $\mathrm{TC} \rightarrow \mathrm{OI}^{*}(\mathrm{H} 3)$ & .336 & .027 & 12.226 & $.001 * *$ \\
\hline $\mathrm{DL} \rightarrow \mathrm{TC} \rightarrow \mathrm{OI}^{*}$ & .335 & .025 & 16.322 & $.001 * *$ \\
\hline Mediation Tests & \multicolumn{2}{|c|}{$\begin{array}{c}\text { Sobel Test } \\
7.983 \\
\end{array}$} & $\begin{array}{c}\text { Aroian Test } \\
7.968 \\
\end{array}$ & $\begin{array}{c}\text { Goodman Test } \\
7.998 \\
\end{array}$ \\
\hline
\end{tabular}




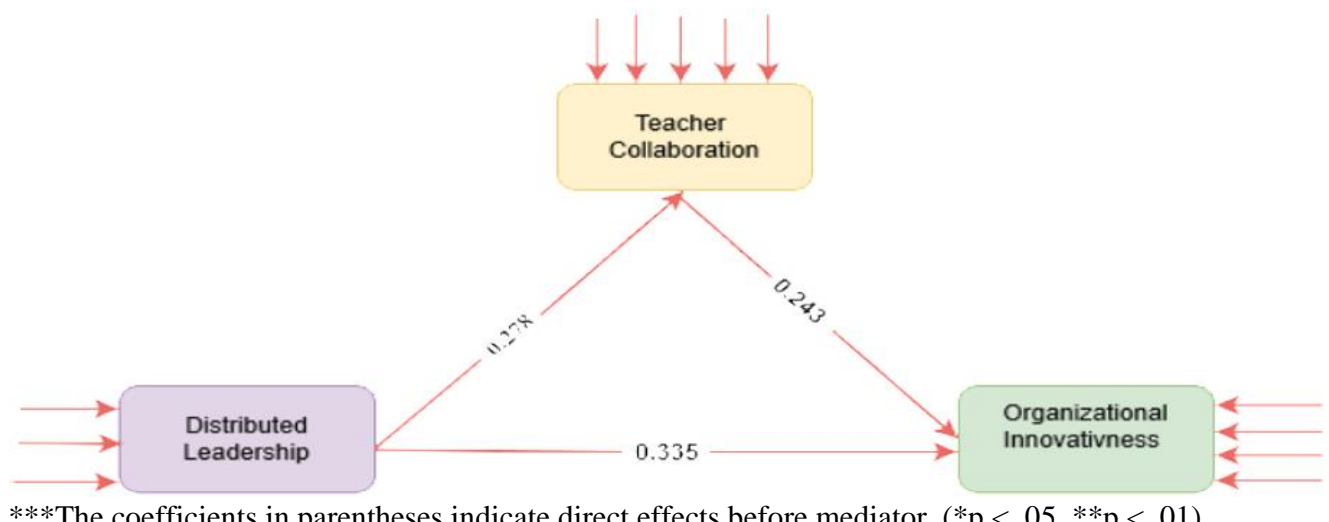

$* * *$ The coefficients in parentheses indicate direct effects before mediator. $(* \mathrm{p}<.05, * * \mathrm{p}<.01)$.

Figure 2. Mediation role of the hypothesis

To test the mediating effects between distributed leadership and organizational innovativeness, the procedures suggested and assumptions of mediation effects required were followed and multiple linear regression analysis was applied using via Mplus 6.2 and AMOS 23 program. As shown in Table 4, the standardized effects of the DL styles on OI $(\beta[$ Model 1] $=.40, \mathrm{p}<.001)$ and DL styles on TC $(\beta[$ Model 2] $=$ $.28, \mathrm{p}<.001)$ are found to be statistically significant. Similarly, the standardized effects of the TC on OI $(\beta$ [Model 3] $=.34, \mathrm{p}<.001$ ) is regressed significantly. These results yielded supported H1, H2, and H3. This means that it is possible to say that the DL independent variable has some statistically significant effects on OI dependent variables. After entering the mediator, the effect of DL on OI and TC on OI decreased ( $\beta$ [Model 4] $=.34, p<.001)$ and the mediation effect of distributed leadership between organizational innovativeness was significant. This means that $\mathrm{H} 4$ was supported and the model results indicated that distributed leadership styles affect organizational innovativeness partially through teacher collaboration. The direct, indirect, total effects are also reported to see the power and level of relationships among the variables in Table $5[40,41]$.

Table 5. Direct, indirect, and total effect coefficients of the latent variables*

\begin{tabular}{cccccc}
\hline Model & \multicolumn{4}{c}{ Model 1 } \\
\hline Hypothesis & Direct & SE & Indirect & SE & Total \\
$\mathrm{DL} \rightarrow \mathrm{TC} \rightarrow \mathrm{OI} *$ & .335 & .026 & .067 & .010 & .402 \\
\hline *All the values of direct, indirect and total effects in the table are \\
standardized beta coefficients.
\end{tabular}

According to Table 5, DL has a direct effect on OI $(\beta[$ Model 4$]=.34, \mathrm{p}<.001)$; indirect effect $(\beta$ $[$ Model 4] $=.07, \mathrm{p}<.001)$ and total effect $(\beta[$ Model 4$]=.40, \mathrm{p}<.001)$. This means that the distributed leadership style in the prediction of organizational innovativeness and teacher collaboration have a partially mediated effect on the relationship between distributed leadership and organizational innovativeness. As seen in Table 4, Sobel, Arion and Goodman test results are also supported this finding. EA scholars have focused on the effects of distributed leadership on school process, structures, culture, teaching and learning for the last four decades [7-9] and concluded that it has a direct and indirect effect on teaching and organizational innovativeness via teacher collaboration, teacher self-efficacy, and commitment. Innovateveness is important for two aspects. First, it can support and add value educational innovation for improving students' learning outcomes and the educational quality of school organization. The other aspect is indirect effect such as increasing efficiency, maximising the "bang for the buck" [42] and occuring the changes necessary to adapt to rapid changes in social and technological transformations. In the present study, we examined the direct and indirect relationship of distributed leadership on teacher collaboration and organizational innovativeness. Our study supported previous research findings, emphasizing that school principals who focused on teaching and ensured teacher collaboration are key actors for school improvement.

The first hypothesis of our paper refering to the impact of school principals' distributed leadership on organizational innovativeness. The finding claims that school principals distributed leadership behaviors affected organizational innovativeness. This assumes that is school principals displayed distributed leadership behaviors, they encourage teachers to improve and exchange new ideas for teaching practices. Additionally, 
they ensure teachers to open to changes in teaching and learning processes and practices, and to strengthen their problem-solving strategies. Paralel to our finding, some researchers found out the relationship between these two variables $[9,11,22]$. They claimed that if school principals empowered teachers and share their authority with them, they built a trustful and innovative atmosphere where teachers could be more creative in this school climate.

Our second hypothesis assumes that school principals' distributed leadership influenced teacher collaboration. The finding indicates that school principals' distributed leadership have a positive effect on teacher collaboration. This means that if school principals' distributed leadership behaviors increase, they ensure the solidarity climate for teachers and in the climate, teachers share their ideas and classroom practices with their collegaues. Similiarly, some other researchers found out that school principals' distributed leadership has a significant impact on teacher collaboration [21, 28, 27]. They expressed that if school principals created a collaborative, cooperative atmosphere for their teachers, they encouraged their teachers to exchange their reflective ideas about classroom practices among them. In Turkey, school principals mostly did not exhibit transformative and technical management behaviours on the contrary, they behaved as administrative managers $[43,44]$.

The third finding of the study expresses that teacher collaboration affected organizational innovativeness. This implies that when teacher collaboraton increased in a school, organizational innovativeness also increased. This finding is consistent with the previous studies [22, 23, 33] In the studies, researchers claimed that if teacher collaboration is well-built in the schools, teachers can easily exchange their reflective ideas, open to change and use alternative and innovative methods and practices in teaching such as blended learning, gamification, computational thinking, experiential learning [45]. Shortly, teacher collaboration makes teacher develop their professional development. Although teacher improvement program was conducted in 2010, which is about school-based teacher professional development, its sustainability ignored in Turkey [46]. Nowadays, there is lack of structures to support teacher professional development in the educational system $[47,48]$, and policy makers should establish structures and processes for teachers to access alternative and innovative practices in teaching. We lastly expressed that school principals' distributed leadership behaviors affected organizational innovativeness via teacher colllaboration indireclty. Shortly, teacher collabration is partially mediated effect between distributed leadership and organizational innovativeness in our model. When principals share their powers with teachers and create a common vision for their schools, they will create an appropriate climate for teachers to work collaboratively. In this way, by strengthening teachers, they will contribute to their professional development and organizational innovativeness.

\section{CONCLUSION}

In conclusion, digital transformation having an effect on social, economic, and technological structures force educational systems to focus on school improvement, teacher collaboration, innovative teaching and learning processes. In more recent research, innovation was putted into words with innovation in teaching including problem-solving skills of teachears and focusing on changes of school and classrooms rather than meaning of radical change. Discussions on innovative education among researhers are related several points in the literature. However, we summarize these different percpectives about innovation in education with the aspect of teaching practices, innovative practices by teachers such as blended learning, gamification, computational thinking, experiential learning, and with the perspective of developing the students' skills required in complex modern and rapidly changing societies. Both the innovative practices applied by teachers and the instructional methods and approaches which are required teachers' collaboration and positive school climate, that focus on improving students' skills have some implications for students, teachers, leadership and school development. From a broader perspective, the impact of organizational innovativeness on student outcomes in may be directly related to the welfare and development of countries.

Although the present study provides substantial implications with regard to the relationship between leadership, organizational innovativeness via teacher collaboration, the findings should be considered with the limitations inherent in the study. Firstly, the views about leadership, teacher collaboration and organizational innovativeness are based on teachers' perceptions, referring that they are asked to judge their school principals' distributed leadership practices and the atmosphere they want to create. This involves the potential to undermine the objectivity of the data. Second, we obtained data from TALIS 2018 and this is a quantitative research. As a sample we chose Turkey. For further researchers, we recommended that they conduct a qualitative research and they deeply examine the relations among these three variables. Additionally, they should select some else countries and compared the situations of the countries. Finally, they should conduct a research with multi-level structural equation in schools and between schools. 


\section{REFERENCES}

[1] S. Liu ve P. Hallinger, "Principal instructional leadership, teacher self-efficacy, and teacher professional learning in China: Testing a mediated-effects model," Educational Administration Quarterly, vol. 54, no. 4, pp. 501-528, 2018.

[2] N. Ozdemir, "Principal leadership and students' achievement: Mediated pathways of professional community and teachers' instructional practices," KEDI Journal of Educational Policy, vol. 16, no. 1, pp. 81-104, 2019.

[3] K. A. Leithwood ve D. Jantzi, "Transformational school leadership for large-scale reform: Effects on students, teachers, and their classroom practices," School Effectiveness and School Improvement, vol. 17, no. 2, pp. 201-227, 2006.

[4] J. Sun ve K. A. Leithwood, "Transformational school leadership effects on student achievement," Leadership and Policy in Schools, vol. 11, no. 4, pp. 418-451, 2012.

[5] J. Pisapia, D. Reyes-Guerra ve E. Coukos-Semmel, "Developing the leader's strategic mindset: Establishing the measures," Leadership Review, vol. 5, no. 1, pp. 41-68, 2005.

[6] O. Coban, S. Ozdemir ve J. Pisapia, "Top managers' organizational change management capacity and their strategic leadership levels at ministry of national education (MoNE)," Eurasian Journal of Educational Research, vol. 19, no. 81, pp. 129-146, 2019.

[7] R. H. Heck ve P. Hallinger, "Testing a longitudinal model of distributed leadership effects on school improvement," The Leadership Quarterly, vol. 21, no. 5, pp. 867-885, 2010.

[8] M. Ozdemir ve E. Demircioglu, "Distributed leadership and contract relations: evidence from Turkish high schools," Educational Management Administration \& Leadership, vol. 43, no. 6, pp. 918-938, 2015.

[9] A. S. Bryk, P. B. Sebring, E. Allensworth, S. Luppescu ve J. Q. Easton, Organizing schools for improvement: Lessons from Chicago, Chicago: University of Chicago Press, 2010.

[10] K. Leithwood, A. Harris ve D. Hopkins, "Seven strong claims about successful school leadership revisited," School Leadership \& Management, vol. 40, no. 1, pp. 5-22, 2020.

[11] V. M. J. Robinson, C. Lloyd ve K. Rowe, "The impact of leadership on student outcomes: An analysis of the differential effects of leadership types," Educational Administration Quarterly, vol. 44, no. 5, pp. 635-674, 2008.

[12] N. Özdemir ve M. T. Yalçın, "Ortaöğretim öğrencilerinin akademik başarisi ile okul ve öğrenci düzeyi değişkenler arasindaki ilişkilerin incelenmesi: İki düzeyli yol analizi," Eğitim ve Bilim, vol. 44, no. 200, pp. 93-116, 2019.

[13] J. Blasé ve J. Blasé, "Effective instructional leadership: Teachers' perspectives on how principals promote teaching and learning in schools," Journal of Educational Administration, vol. 38, no. 2, pp. 130-141, 2000.

[14] R. Goddard, Y. Goddard, E. Sook Kim ve R. Miller, "A theoretical and empirical analysis of the roles of instructional leadership, teacher collaboration, and collective efficacy beliefs in support of student learning," American Journal of Education, vol. 121, no. 4, pp. 501-530, 2015.

[15] H. Hulpia, G. Devos ve H. Van Keer, "The influence of distributed leadership on teachers' organizational commitment: A multilevel approach," The Journal of Educational Research, vol. 103, no. 1, pp. 40-52, 2009.

[16] P. M. Senge, The fifth discipline, New York: NY: Doubleday Currency, 1990.

[17] J. Ko, P. Hallinger ve A. Walker, "Exploring school improvement in Hong Kong secondary schools," Peabody Journal of Education, vol. 87, no. 2, pp. 216-234, 2012.

[18] F. Damanpour ve T. Childers, "The adoption of innovations in public libraries," Library and Information Science Research, vol. 7, no. 3, pp. 231-246, 1985.

[19] F. Damanpour, Evan ve W. M., "Organizational innovation and performance: The problem of organizational lag," Administrative Science Quarterly, vol. 29, no. 3, pp. 392-409, 1984.

[20] A. Subramanian ve S. Nilakanta, "Organizational innovativeness: Exploring the relationship between organizational determinants of innovation, types of innovations, and measures of organizational performance," Omega, vol. 24, no. 6, pp. 631-647, 1996.

[21] Y. Liu, M. S. Bellibas ve S. Printy, "How School context and educator characteristics predict distributed leadership: A hierarchical structural equation model with 2013 TALIS data," Educational Management Administration \& Leadership, vol. 46, no. 3, pp. 406-427, 2018.

[22] F. Geijsel, P. Sleegers, R. Stoel ve M. Krüger, "The effect of teacher psychological, school organizational and leadership factors on teachers' professional learning in Dutch schools," The Elementary School Journal, vol. 109, no. 4, pp. 406-427, 2009.

[23] D. C. Nielsen, A. L. Barry ve P. T. Staab, "Teachers' reflections of professional change during a literacy-reform initiative," Teaching and Teacher Education, vol. 24, no. 5, pp. 1288-1303, 2008.

[24] C. Freeman, K. O'Malley ve F. Eveleigh, Australian teachers and the learning environment: An analysis of teacher response to TALIS 2013: Final report, ACER, 204, Melbourne, 2014.

[25] P. Groon, "Distributed leadership as a unit of analysis," Leadership Quarterly, vol. 13, no. 4, p. 423-451, 2002.

[26] J. P. Spillane, "Distributed leadership," In The educational forum, Taylor \& Francis, June 2005.

[27] A. Harris, K. Leithwood, C. Day, P. Sammons ve D. Hopkins, "Distributed leadership and organizational change: Reviewing the evidence," Journal of Educational Change, vol. 8, no. 4, pp. 337-347, 2007.

[28] R. H. Heck ve P. Hallinger, "Assessing the Contribution of distributed leadership to school improvement and growth in math achievement," American Educational Research Journal, vol. 46, no. 3, pp. 659-689, 2009.

[29] OECD, "TALIS 2018 Technical Report," 2019. [Online] Available: www.oecd.org/publications/talis-2018-resultsvolume-i-1d0bc92a-en.htm

[30] S. Gumus, O. Bulut ve M. S. Bellibas, "The relationship between principal leadership and teacher collaboration in Turkish primary schools: A multilevel analysis," Education Research and Perspectives, vol. 40, no. 1, pp. 1-29, 2013.

Int. J. Eval. \& Res. Educ. Vol. 9, No. 4, December 2020: 903 - 911 
[31] A. Bandura, "The explanatory and predictive scope of self-efficacy theory," Journal of Social and Clinical Psychology, vol. 4, no. 3, pp. 359-373, 1986.

[32] V. J. Marsick ve K. E. Watkins, Informal and incidental learning in the workplace, London, UK: Routledge, 1990.

[33] L. Darling-Hammond, "Teacher education around the world: What can we learn from international practice?" European Journal of Teacher Education, vol. 40, no. 3, pp. 291-309, 2017.

[34] P. Floyd, Organizational change: Organizations 07.06, USA: Wiley, 2002.

[35] L. Cohen, L. Manion ve K. Morrison, Research methods in education, 8. Ed., London: Routledge, 2018.

[36] B. G. Tabachnick ve L. S. Fidell, Using multivariate statistics, New York: Pearson, 2013.

[37] R. M. Baron ve D. A. Kenny, "The moderator-mediator variable distinction in social psychological research: Conceptual, strategic, and statistical considerations," Journal of Personality and Social Psychology, vol. 51, no. 6, pp. 1173-1182, 1986.

[38] B. M. Byrne, Structural equation modeling with AMOS: Basic concepts, applications, and programming, 2. Ed., New York: Routledge, 2010.

[39] R. B. Kline, Principles and practice of structural equation modeling, New York: The Guilford Press, 2011.

[40] N. U. Hadi, N. Abdullah ve I. Setosa, "Making sense of mediating analysis: a marketing perspective," Review of Integrative Business \& Economics Research, vol. 5, no. 2, pp. 62-76, 2016.

[41] D. P. Mackinnon ve J. H. Dwyer, "Estimating mediated effects in prevention studies," Evaluation Review, vol. 17, no. 2, pp. 144-158, 1993.

[42] OECD, Measuring innovation in education: A new perspective, educational research and innovation, Paris: OECD Publishing, 2014.

[43] Ö. Çoban, "Examination of the relationship between top managers' organizational change management capacity and their strategic leadership levels at ministry of national education (MoNE)," Unpublished dissertation, Gazi University, Ankara, 2016.

[44] T. E. Harris, "Organizational communication: focusing on leadership behaviour and change management," 1986. [Onine]. Available: https://eric.ed.gov/?id=ED278053

[45] A. Paniagua ve D. Istance, Teachers as designers of learning environments: The importance of innovative pedagogies, educational research and innovation, Paris: OECD Publishing, 2018.

[46] MEB, Okul Temelli Mesleki Gelişim, Ankara: MEB Yayınları, 2010.

[47] R. Atasoy ve Ö. Çoban, "Relationship between learning strategy and socio-economic situation, ict using skills, age, educational status, problem solving skills," International Journal of Education Technology and Scientific Reserch, vol. 5 , no. 11 , pp. $1-39,2020$

[48] S. S. Seferoğlu, "Öğretmen Yeterlikleri ve Mes. Gel," Bilim ve Aklın Aydınlı̆̆ında Eğitim, vol. 58, pp. 40-45, 2004. 